\title{
Why Customers Intend to Use Express Delivery Services
}

\author{
Sri Setiyawati (Corresponding author) \\ Graduate School of Economics, Sebelas Maret University, Indonesia \\ E-mail: srisetiyawati84@gmail.com
}

Budhi Haryanto

Faculty of Economics and Business, Sebelas Maret University, Indonesia

Received: June 25, 2016 Accepted: July 25, $2016 \quad$ Published: August 2, 2016

doi:10.5296/csbm.v3i2.9661ＵRL: http://dx.doi.org/10.5296/csbm.v3i2.9661

\begin{abstract}
The aim of this research was to better understand the effects of products quality, price reasonableness, brand image, and attitude towards customer's intention. This research was guided by four research questions: What product quality has a positive influence on express delivery services a positive attitude? What price reasonableness positive influence on attitude to use express delivery services? What positive effect on brand image expresses delivery services? What positive attitude influence on intention to use express delivery services? The methodology employed was survey of 100 customers plus in-depth interviews with courier service operators. Interviews and survey were conducted from August to October 2015. This research was used SEM techniques for data analyze. The results confirmed there was no relationship between products quality, price reasonableness and attitude. Furthermore, brand image has influence attitude. The mediating role effects of costumer's attitude for product quality, price reasonableness and brand image towards customer's intention offer new insight into antecedents on costumer's intention in a high influence. This study presents an original contribution to understanding brand image effect and its attributes either directly or through attitude towards customer's intention is determine.
\end{abstract}

Keywords: Product Quality, Price Reasonableness, Brand Image, Attitude, Customer's Intention 


\section{Introduction}

Competitive advantage is likely to depend on market orientation, which means fosters behaviors that lead to customer's perception of superior value. Market orientation implies to customer's needs and delivering solutions and services that meet customer's needs, which indicates customer orientation. The phenomenon of attitude and intention to use express delivery service part of orientation to the customers is an interesting issue to be studied. Previous studies show inconsistency attitudes and intentions models relating to express delivery services (Li \& Petrick, 2008). This is due each study is based on the object and different settings. These conditions provide opportunities to design an alternative model capable of elaborating phenomenon to be observed.

The alternative model is built based on five variables: products quality, price reasonableness, brand image, and attitudes which explain its influence on intention to use express delivery services. Thus, prediction models of individual behavior intention can be explained as follows: Product quality needs to be examined because these variables effectively to influence customer attitude (Stank et al., 2003; Richey et al., 2007; Rafid \& Jaafar, 2007). However, different findings on influence customer behavior and product quality services performed by Mentzer et al., 2001) indicating customer perceptions about product quality is very relative and changeable nature because of individual psychological influence.

In a context of product's quality services, including express delivery services (EDS) emphasize multiple components and conceptually different dimensions. Grönroos (1990) and Sze et al. (2013) proposed that measure product quality on service consists of three dimensions: (1) technical quality; (2) functional quality and (3) image. Technical quality is a component related to the output of services received. While functional quality is a component related to service delivery quality. The image is a component associated with company profile, reputation, attractiveness. Russell \& Hoag (2004); Narayanan et al. (2009) have several attributes in context express delivery like timeliness, orders accuracy, information quality, availability and personal relationships quality. Overall dimensions punctuality has enormous influence (Beinstock et al., 2010; Rahman, 2006; Mentzer et al., 2007). Hence, EDS Standards adopted by the Global Express Association (Frontier Economics 2015) requires that express delivery attributes are: global reach, reliability, transparency, speed, security. Furthermore products quality re-tested for effectiveness in this study.

Price reasonableness considered important in attitudes formation toward express delivery services. This is due that price used by a customer to evaluate a product, both products services, and goods. Prices can give positive or negative perceptions. In this study price reasonableness needs to be investigated because there are still inconclusive understanding between price and behavioral intentions. The inconclusive understanding shown by several studies that a significant relationship is that customer behavior intention is influenced by the price of services is low (Keaveney, 1995). On the others side studies show no significant relationship that customer's intention to behave is influenced by the high cost of service (Mittal et al., 1998). Imran et al. (2010) found that price reasonableness and consumer buying behavior is related to one another. The main reason customers switched because of price, for 
example, expensive, unreasonable and pricing policies that cannot be trusted (Peng \& Wang, 2006).

Customers in choice determining by comparing price with services quality provided. Customer well-done price reasonableness of service innovation is acceptable, then it will have a positive attitude towards, so it can receive a higher price. It can be said that a high-quality service will consider customers even to pay higher fees than a lower quality of service (Chitty et al., 2007). Thus, price reasonableness re-tested for effectiveness.

Brand image is a perception in customers' minds a good impression of a brand (Hawkins \& Coney, 2004). A good impression could arise if a brand has an impression of superior, good reputation popular, good and excellent service (Aaker, 1997; Kotler \& Keller, 2012). The brand image may elaborate memories, beliefs and preferences of customers' attitude toward a brand and corporate image perceptions influence on intention and brand purchase behavior (Hsieh et al., 2004; Karampour \& Ahmadinejad, 2014). Vahid \& Aidin (2012) find the attitude towards brand effect on product choice, but no significant relationship between individual intentions and product choice. This inconsistency conditions about a diversity of perception of value to the brand image. Thus, brand image re-test to look at the consistency of customers' attitudes and intentions.

The nature marketing context of customer orientation, attitude considered influence intention to use express delivery services. The attitude formation can be seen from Multi-dimensional models. Its view that attitude as a construct of three components: cognitive, affective and conative (Rosenberg \& Hovland, 1995; Chang, 2011). The research focus is to explain model predictions attitudes and intentions on express delivery services. Multi-dimensional models used to describe attitude willingness of individuals to determine customers' attitude on service delivery in express. Based on research Ehigie (2006) show that positive consumers attitude is a critical factor associated with customer expectations, perceived service quality, commitment to the product, brand or service companies that generate purchase intent. Donio et al. (2006); Brunner et al. (2008) indicate that positive customers' attitude are not sensitive to negative information and positive attitude fully take effect to a brand. Thus, attitude used to see consistency as mediation of customer goodwill. Here, researchers wanted to know individual's wish through attitude dimension as a mediating variable.

The intention to use express delivery services is adopted from several earlier studies designed intention as a dependent variable (Wang et al., 2010). This is because that study was intended to offer an understanding of how customers can improve the use of services. Customers wish to use services are based on beliefs and values related to the acting of using these services. One possible different cause that intention based on experience has been done; or information obtained from an environment (Anoraga, 2000). In the context of study intention was analyzed by using the Theory of Reasoned Action = TRA introduced by Fishbein \& Ajzen (2010) and using the Theory of Planned Behavior = TPB introduced by Ajzen (2001). Under the TRA, a decision to act is the best forecasts in individual intentions. It can be said that a person intention is considered describing behavior and attitude of directing subjective norm (Chang, 2011). While TPB developed the TRA, especially is the addition of perceived 
behavioral control factors. So the study used combined TRA and TPB

\subsection{Problem Statement}

Conceptualization of variables to be studied, namely: product quality, price reasonableness, brand image and attitude influence intention to use express delivery services. To encourage practices this study addresses the following questions: Is product quality has a positive influence on express delivery services a positive attitude? What price reasonableness positive influence on attitude to use express delivery services? What positive effects on brand image express delivery services? What positive attitude influence on intention to use express delivery services?

\subsection{Research Objectives}

The general purpose of this study is to look at the effect of product quality, price reasonableness, brand image and attitude influence on intention. Especially, this study aims to figure product quality has a positive influence on attitude; price reasonableness positive influence attitude; brand image positive influence attitude; and attitude positive effect on the customers' intent to use express delivery services.

\subsection{Research Contributions}

The contribution of this study is to offer a new approach that is more comprehensive, namely elaborate dimensions of product quality, brand image, price reasonableness, and attitude to assess the extent of its significance to customer's intent to use express delivery services; contribute to the science of management. Especially to understand the effect of product quality, price reasonableness, brand image, attitude to assess the extent its significance to customer's intent on express delivery services. Then, show main factors that explain highest variation in customer's intent on express delivery services company will help policymakers to reform corporate marketing service significantly and qualified; a pioneer in customer's intent perspective to use express delivery services. The findings of study will fill chasms theoretical to explore role of attitudes that decide customer's intent to use express delivery services and mainstreaming for further studies in marketing services.

\section{Literature Review}

In a literature review, the relevant theory is explained by a model. The diversity of references that occur can be explained by providing a common view on earlier studies and research will examine. Here researchers wanted to know individual's wish through sequence dimensions of knowledge, feelings and intentions to use express delivery services. The discussion begins with account intention theory became basis study. This follows by attitude, products quality, price reasonableness, and brand image.

\subsection{Intentions}

Cognitivism focused intention to use express delivery services as a variable-mediated by attitudes toward product quality, price reasonableness and brand image (Anoraga, 2000). The intention is individual's need that requires beliefs and values assigned to actions on specific 
objects. It is a self-direction to execute sealed actions to get in demand results and measured through efforts deployed (Webb \& Sheera, 2006; Ajzen, 2001), based on experience or information in the foreshadowing. Intention assumed factors motivational that influence behavior (Ajzen, 2001). Noted that relationship intention-behavior mostly correlational evidence and could not explain intentions on behavior causality. An intention of causing behavior change and how attitude incorporate other factors influence behavior. Earlier research, action intentions specified by the Theory of Reasoned Action $=$ TRA proposed by Fishbein \& Ajzen (2010). TRA components applied well-defined intentions, namely: trust, motivation; attitude guiding behavior, subjective norm; and intention to act.

Trust factor as main elements that determine a consumer's intention to do certain actions (Hong \& Cha, 2013) consumer's belief will not act opportunistically. Trust is a mental picture thought and opinions are influenced by social context. Mowen \& Minor (2001) shows consumer belief is a customer's subjective perception about benefits and product quality on different attributes. Trust idea is fundamental in developing consumers' attitudes and intentions (Pei et al., 2014) keep promises and commitments. Subjective norm components refer to a subjective judgment of others individual preferences (Ajzen, 1991). Chang (2011) show a relationship indicator subjective norm on attitudes and intentions in behavior shows inconsistent results, namely that subjective norms affect customer's intention. Different studies show subjective norm indirect effect on intention through attitude (Tarkianen \& Sunqvist, 2005).

TRA stated that intention is the best predictor of behavior and intentions influenced by attitude and subjective norm factor. Several researchers have demonstrated successful use of TRA in predicting a relationship between intention and behavior. Intention someone described attitude directing behavior and subjective norms (Chang, 2011). Attitude refers to individual perception toward certain behaviors (Werner, 2004). Based on these research, derived the fact that customers' positive attitude towards services will increase intention to use services. In the study Ajzen (1991) added perceived behavioral control / PBC in determining individual behavioral intention, known as TPB.

PBC is an added predictor for joint intention attitudes and subjective norm. Webb \& Sheeran (2006) show that intention determining of behavior, besides the PBC can predict direct to behavior or mediate relationship between intention and behavior. TRA and TPB theory describes attitude directing behavior influenced subjective norm and perceived behavioral control. So intention can be explained attitude leads to behavior refers to an individual's perception either positive or negative towards certain behaviors. Subjective norm refers to social factors and characteristics in real life. Percept of behavioral control refers to individual perception about ease certain behaviors will perform.

\subsection{Attitude}

Attitude is a meaningful variable considered influence intention. In this situation attitude can mediate product quality, price reasonableness and brand image on intention to use express delivery services. Previous studies indicate attitude as ideas, thoughts, ideas and emotions having predisposes behavior (Rosenberg \& Hovland, 1995; Fishbein \& Ajzen, 2010). Attitude 
consistently has a positive relationship to intention to use (Tarkianen \& Sundqvist, 2005). Attitude applies to the quality assessment of like or dislike of a person against the behavioral assessment. This means that if a customer has a positive attitude towards a product, the customer realizes intention to use. Li \& Petrick (2008) noted inconsistency explain attitudes toward product services. This inconsistency shows that inquiry becomes not brought orders for posture concept in defining form process of customer attitudes toward product services. Gaps offer opportunities for these studies to develop a model that can apply to this issue. Problematics of customer's attitude is a tendency to react positively or negatively to service product. In this context, attitude as a predisposition to behaves intention to use.

\subsection{Products Quality}

Products' merchandising goods and services is a key factor delivers value to customers. Have a tangible product attribute, service features, design, performance quality, brand name and packaging. According to Kotler \& Armstrong (2010) product a quality considerable impact on products performance or services, so associated with value and customer satisfaction. Objective quality refers to technical properties are measured. Products can be verified through process and quality control including product features, product performance, and durability. Wankhade \& Dabade (2006) defines it differently that product quality is determined by how customers perceive product's quality on the market. Perceptual quality refers to consumer value judgment. Product's quality includes features and products characteristics or services that rely on its ability to fulfill or implied needs. That way product quality as suitability for purpose or conformance to requirements.

This study focuses on perception quality, Aaker (1997) argues it can show a superior differentiation of products or services and make consumers think selective towards a brand. Perception quality influenced factors such as earlier experience, education level, and perceived risk and situational variables such as purchasing purpose, purchasing situation, time urgency, and social background. The company engaged services to focus on service quality as a strategy compete (Chaoprasert \& Elsey, 2004). Customers can receive more benefits position itself better than the competition Studies Parasuraman et al. (2005); Goode \& Harris (2006) finds service product has influence attitudes and intentions of customer behavior. Similar research (Cronin \& Taylor, 1992) showed quality perception is a significant predictor customer behavior affects behavioral intentions. Ahmad \& Kamal (2002) showed service quality is antecedent intention to behave and more influential rather than attitudes.

Product quality is a disparity between the actual product and product expected from customer's outlook. Gaps actual product performance and product perception requires less concern to a research of product perceived quality with other marketing variables such as customer satisfaction and purchase intention. Ahire et al. (1996) adopt products quality with attributes: performance, reliability, suitability and durability. Lefkoff-Hagius \& Mason (1993) described product quality is measured by three attributes are characteristics, benefits, and imagery. The third attribute influencing consumer behavior and preferences in deciding of choice. Products characteristics are qualities that define a product or service. Benefits refer to an individual or an interest in information perceived while referring to the image formed by 
the individual's subjective interpretation of phenomenon perception. Study Lee \& Tan (2003) show that meaningful influence attributes well in exploring effects of consumers' judgment of product quality, but product characteristics and image is not significant.

At a consumers perspectives products quality has two categories, namely: objective quality and perceived quality. Services quality consisting of equipment used (physical qualities), image (reputation of the company), and interaction between contact personnel and customers (interactive quality). The research context, subjective quality perspective view product quality saw on perceived quality because it focuses on a consumer's subjective assessment. Quality perception can show a superior product differentiation. According to Grönroos (1984), product quality component is a quality of technical, functional and image quality. Liu et al. (2014) indicate that express delivery services based timeliness. Previous studies conducted by Kannan \& Tan (2002); Cakravastia \& Takahashi (2004) costs (freight rates and prices) and risk (reliability, losses, and collateral) on product quality are defined as perception quality of customer to express delivery services. Mentzer et al. (2007) indicate reliability and quality of personal relationships as criteria outlined against selecting intention services. Research Fawceet et al. (1996) indicates that performance is affected by delivery service: fast delivery, reliable, high-quality service, responsiveness, innovative, and competitive pricing. Colonna (1997) indicate that product quality indicators used by Federal Express: regulatory, reliability, completeness, correctness, harmfulness, productivity.

In this study, product quality is defined as quality perception to express delivery service/EDS. Express delivery services is a method of communication and transportation that serve documents, packages, and goods delivery from door to door in a certain time period (Daniel Sokol, 2003). EDS refers to goods / relatively high value documents (important letters, bills, tenders, reports, certificates) delivery, a mixture of air and land transport modes time-sensitive (accepted until all the goals in a 24-72 hours), EDS nature are door to door, pick-ups, time bound, insurance shipment, reliability, safety and security of shipment, trace and tracking facilities, and proof delivery barcode (Oxford Economic Forecasting, 2009). Customers decision to use services based on personal perception of product, not on factual certainty, subjective perception is substantially more important than their knowledge of objective reality (Schiffman \& Kanuk, 2004).

Product quality measures implemented by corporation include lead time, regularity, reliability, completeness, flexibility, truth, harmfulness, productivity. Colonna (1997) show product quality indicators applied by Federal Express: Regularity; Reliability; Completeness; truth (correctness); risk of damage (harmfulness); Productivity. Similar to product quality attributes Fawcett et al. (1996); Colonna (1997), standards the Global Express Association requires express delivery attributes are: Global Reach, or ability to send goods anywhere; Reliability (know where time of receipt); Transparency or can trace consignments; Speed; Security or find safe delivery of goods in supply chain. Then the study used on base the Global Express Association Standard (Frontier Economics 2015), i.e., Global Reach; Reliability; Transparency; Speed and Security.

\subsection{Price Reasonableness}


Price reasonableness is considered in this study because it can create attitudes formation toward express delivery services. Customer cognitive conception, price factor is something that must be paid to get some type of product (Zeithaml, 1988). In delivery context, in addition to price as a form of sacrifice that had to be paid for services but also imposed as insurance cost (Gerrard \& Cunningham, 2004). One possible cause of decision to switch behavior to products / services of others, according to Colgate \& Hedge (2001); Peng \& Wang (2006) due to price.

Based on studies Imran et al. (2010) and Lee (2012) indicated that price reasonableness will be assessed in accordance with service quality, both significantly associated with a positive attitude (Oliver, 1997) depends on equity principle. Known that customers make choices by comparing price with service quality provided. Service performance is a service perceived (Rahman, 2006; Mentzer et al., 2007). Express delivery service factors considered is shipments timeliness, and reposition price is accepted, customer to be positive about product / service and receive a higher price. Karampour \& Ahmadinejad (2014) mention that price sensitivity hasn't effect on intentions customer purchase. Then price reasonableness dimension used to look for consistency against customer intention.

\subsection{Brand Image}

The company's brand can be same as brand product / service is a marketing communication activities enables a company to obtain an image. The brand company confirmed that company stands behind product or service described by a product or service that will be used customers (Aaker, 2004). Brand image is important variables considered in this study because it can affect customer attitudes to intended use by express delivery services.

Based on research Aaker (2004), Anisimova (2007), Blomback et al. (2007), Martenson (2007), Da Silva et al. (2008) indicate that brand image is a type of association that comes to mind customers when considering a brand, association a certain image that is convincing to brand. On the corporate side, a brand is used to sell products at low prices and transformed to change the added value on quality and service. Indeed, brand image and corporate image perception influence on intention and brand purchase behavior (Hsieh et al., 2004; Karampour \& Ahmadinejad, 2014). This is due to customers tending to use services products when customers require (Choi \& Fishbach, 2011). Based on studies Matthiesen \& Phau (2010) indicate that brand image is formed by a perception of service quality. Blomback et al. (2007) indicate brand was built by the interaction with the unity of the features that are intangible and tangible representing the brand. Research Valentini et al. (2011) indicate that brand selection decisions process by customers evolves over time, such as a desire to use the product / service, tolerance prices and intention to recommend products or services. The quality of service perceived customer (Aydin \& Ozer, 2005) is a form of evaluation to determine the perception of a brand image, (Pina et al., 2006) supplementary service affects the company's image, especially brands that already have an image of a high. Ogba \& Tan (2009) indicate that brand image influence positive attitude. In the context study is able to identify customer's express delivery service company that chooses to convince ourselves in using the express delivery service product that services delivered match what was promised. 
According to Keller \& Lehmann (2003), brand image and attitude affect customer's intention, Nguyen \& LeBlanc (1998) indicates that attitude is more influential than the brand image of the intention. Hsieh et al. (2004) indicate that perception of company's brand big influence on buying behavior. Brand choice decision occurs when customers recognize a symbolic relationship between the brand images with consumer's self-image (Arnould et al., 2005). Vahid \& Aidin (2012) indicate that it cannot predict actual behavior of selection of products / services, due to various reasons, particularly situational reasons. Brand image is measured from consumer's perception of company performance concerned, the basic idea of value-percept diversity, customer satisfaction offer what consumers need and ability to pay to meet the wishes of (Martenson, 2007).

The brand image reflects brand attributes some of strongest associations were intangible, abstract benefits and customer attitude in each category of product that is different from a product brand of products services. Brand image is a perception in the minds of customers about a good impression of a brand (Hawkins et al., 2004). A good impression could arise if a brand has a unique advantage / superior, good reputation, popular, nice and provide the best service (Aaker, 1997; Keller \& Lehmann, 2003; Kotler \& Keller, 2012). Thus, brand variables used to see consistency of attitudes and customers intentions.

\section{Research Framework and Hypotheses}

The approach used in assessing the influence of attitudes and intentions of customers are TRA of Fishbein \& Ajzen (2010) and TPB developed by Ajzen (2001) with adding the perceived behavioral control as a determinant of behavioral intention. Dimensions intention to behave customers essentially determined by three factors: a person's attitude toward behavior, the degree of social pressure one feels about the behavior and the degree of acceptance of control perceived in behavior. The third component of this belief interacts and be a decisive intention that determines a person's behavior. In a study of the influence of the attitudes and intentions of customers in using express delivery services, the proposed research model as follows:

\subsection{Product Quality Positively Influence on Attitude}

Customers use express delivery services for reasons of timeliness submissions (Kannan \& Tan, 2002; Cakravastia \& Takahashi, 2004), at competitive prices (Bienstock \& Royne, 2010; Rahman, 2006; Mentzer et al., 2007) reliable, safety and shipment security (Oxford Economic Forecasting, 2009). Parasuraman et al. (2005); Goode \& Harris (2004) said that service quality is a significant predictor of attitudes (Cronin \& Taylor, 1992) affects intention to behave. Indicate that intentions better than customer's attitude towards products / services quality. The degree of intent describes customer state while attitude is perceived by degree assessment of products / services quality provided by providers. In accordance opinions by Fawcett et al. (1996); Colonna (1997) about product quality attributes this study used the Global Express Association Standard (2015), namely: Global Reach; Reliability; Transparency; Speed and Security are predicted to affect positive attitude. Based on these results, products / services quality included in model and proposed the first hypothesis as follows: 
H1: Product quality positively influence attitude to use express delivery services.

\subsection{Price Reasonableness Positively Influence on Attitude}

Price is an important variable for positive attitudes toward express delivery services formation. Prices give positive or negative consumer perception (Zeithaml, 1988; Gerrard \& Cunningham, 2004) to assess a product, both products services, and goods. Colgate \& Hedge (2001) conclude behavioral effect on the price of customer attitudes about products / services (Peng \& Wang, 2006) price (expensive) and pricing policy cannot be trusted. Based on Imran et al. (2010) studied price reasonableness will be assessed by a customer in accordance with service quality, both significantly with a positive attitude. Different studies Chitty et al. (2007) high-quality services would be considered good even pay more expensive than low-quality services so that services (Rahman, 2006; Mentzer et al., 2007) is difficult to reposition price. Based on the research above, following hypothesis is advanced:

H2: Price reasonableness positively influence attitude to use express delivery services.

\subsection{Brand Image Positively Influence on Attitude}

Based on research Aaker (2004); Anisimova (2007); Blomback \& Axelsson (2007); Martenson (2007); Da Silva \& Syed Alwi (2008) explained that brand image is customer attitudes perception when considering a particular brand, an image can be brand assured. The brand image role elaborating memories, belief and preference of customer's attitude toward a brand (Hsieh et al., 2004; Karampour \& Ahmadinejad, 2014). Keller \& Lehmann (2003) explain that brand image and attitude affect customer's intention. Nguyen \& LeBlanc (1998) indicated attitude is more influential than a brand image on intention. Hsieh et al. (2004) indicate the company's brand perception big influence on buying behavior. Noted that brand image positively influence attitude and intention to use a particular product. Vahid \& Aidin (2012) indicating that it cannot predict actual behavior of products / services selection, due to various reasons, particularly situational reasons. Based on research above, following hypothesis is advanced:

H3: Brand image positively influence attitude to use express delivery services.

\subsection{Attitudes Influence on Intentions}

Attitude consistently affect on intentions (Tarkianen \& Sundqvist, 2005). Customers' positive attitude tends to realize intention (Ajzen, 1991). Based on research (Rosenberg \& Hovland, 1995; Fishbein \& Ajzen, 2010) attitude predisposes behavior. A multi-dimensional as hierarchical sequence model of cognitive, affective and conative (Rosenberg \& Hovland, 1995). Chang (2011) is used to determine attitude effect by intention.

Focus of this study aims to describe the model predictions about attitudes and intentions on express delivery services are to explain individual's desire degree to determine attitude on express delivery services customer. Based on research Anoraga (2000) indicate intention based on experience and motivational factors influence behavior (Ajzen, 2001). Intention described attitude directing behavior and subjective norms and refers to individual's perception that benefits against certain behaviors (Werner, 2004) and increasing the intention 


\section{Macrothink}

Case Studies in Business and Management

ISSN 2333-3324

2016, Vol. 3, No. 2

to use the services. Results of research Webb \& Sheeran (2006) indicate that the intention is the determinant of behavior, in addition to the PBC can predict directly to behavior or mediate relationship between intention and behavior. Based on these studies proposed hypothesis therefore is:

H4: Attitude to use express delivery services mediates the relationship between product quality, price reasonableness, and brand image on customer's intention to use express delivery services.

Based on these descriptions, research model on attitudes and intentions customers using express delivery services in Jakarta this basic framework can be arranged as shown in Figure 1 as follows:

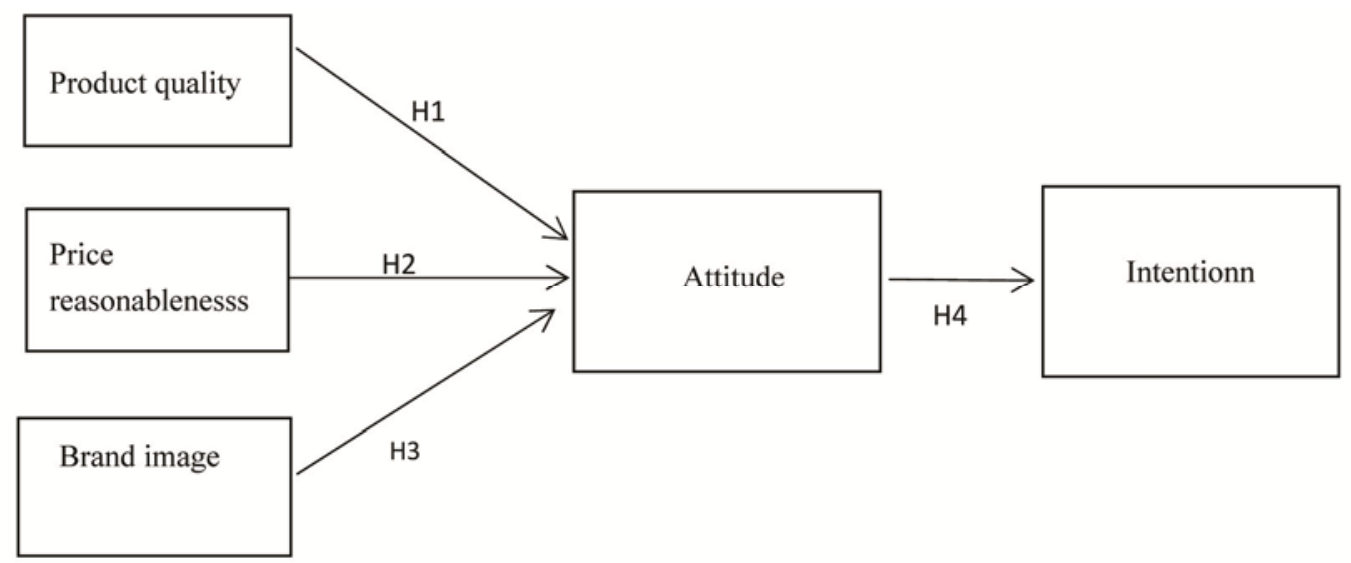

Figure 1. The conceptual model

\section{Methods}

The results are justified scientifically from source and truth, and then research methods are designed to provide a clear and structured basis instruments used to test a hypothesis. In order to achieve these objectives, this chapter will discuss scope, sampling techniques, operational definition and measurement of variables, and statistical methods.

\subsection{The Scope of Research}

This study was designed as an exploratory research to explain a phenomenon (Maholtra, 2007). The research was conducted in Jakarta using survey techniques and data collected are cross-sectional.

\subsection{Sampling Techniques}

The target population in this study is customers who intend to choose express delivery service for shipments / packages / documents in Jakarta chosen as study setting are expected to limit a scope of study so that results are relatively homogeneous. Non-probabilistic sample taken 
with following criteria: (1) sample must have knowledge of courier / courier service / mail / express delivery services intended use; (2) Sample never use a delivery service and intend to use express delivery service at PT. Nugraha path Ekakurir (JNE) during August to October 2015. The determined number of samples of 100 respondents, thus meeting the minimum eligibility criteria for consideration data analysis aspects of Structural Equation Model / SEM (Hooper et al., 2008).

\subsection{Operational Definition and Measurement of Variables}

\subsubsection{Product Quality}

Product quality is defined as an individual's perception of product superiority (Aaker, 1997). In this study variable product quality adopted from Global Express Association (2015). Product quality variable was measured with dimension (a) Global Reach (knowing its wide range) measured using five indications: (1) unlimited range; (2) reach to all corners; (3) a broad range; (4) reach to corner and (5) spread range; (b) Reliability (knowing of reliable service) were measured using five indications: (1) timely service; (2) reliable services; (3) consistent; (4) tested services; (5) ministry assured. ; (c) Transparency was measured using five indications: (1) service is transparent; (2) service is open; (3) services are easily tracked; (4) service is easily detected and (5) explicit service. (d) Speed (fast delivery) was measured using 5 indications (1) fast delivery; (2) timely delivery; (3) delivery smoothly; (4) delivery efficient and (5) delivery reliable. (e) Security was measured using five indications: (1) safe delivery; (2) delivery is guaranteed; (3) are not damaged; (4) shipment is not lost, and (5) shipments protected. Each item was measured using a 5-point Likert scale from strongly disagree to strongly agree.

\subsubsection{Reasonableness Price}

Price is defined as an individual's quality perception. The price factor is a sacrifice that must be paid to get some product type (Zeithaml, 1988; Rahman, 2006; Mentzer et al., 2007). This variable was measured by using 5 price reasonableness indicators (Karampour \& Ahmadinejad, 2014): (1) reasonable rates; (2) reasonable rates; (3) affordable rates; (4) reasonable rates, and (5) usual fare. Each item was measured using a 5-point Likert scale from strongly disagree to strongly agree.

\subsubsection{Brand Image}

Based on the earlier studies, the researcher determined that this variable was measured by using brand image attributes. Brand image is elaborating memories, beliefs and preferences of customer's attitude toward a brand. So the brand image is measured using 5 indications (Hsieh et al. 2014): (1) popular brands image (2) superior brand image. (3) a good brand image. (4) brand image has a good reputation. (5) brand image has a good impression. Each item was measured using a 5-point scale Linkert from strongly disagree to strongly agree.

\subsection{Positive Attitude towards Express Delivery Services}

Attitude is defined as a degree of evaluation like or dislike of a person against an object or product (Ajzen, 1991). This means that if a customer has a positive attitude towards a product, 
the customer tends to manifest intention. Attitude measure multi-dimensional (Rosenberg \& Hovland, 1995) as a construct in a hierarchical manner described through a cognitive, affective and conative sequence.

In this study, express delivery services attitude is measured by using a 5 attitude indications, namely: (1) Glad to express delivery services; (2) Likes to express delivery services; (3) excited to express delivery services; (4) Happy on the existence of express delivery services, and (5) Think positive to express delivery services. Each item was measured using a 5-point Likert scale from strongly disagree to strongly agree.

\subsection{Intention to use Express Delivery Services}

Intention to use express delivery services (Fishbein \& Ajzen, 2010) measure of confidence, motivation; attitudes to direct behavior, subjective norm; intention to act, and perception of behavioral control. This variable was measured by using 5 indications: (1) It will use express delivery services; (2) Want to use express delivery services; (3) Tendency to use the suit express delivery; (4) Willingness to use to use express delivery services; (5) Regarding use of these services in the future. Each item was measured using a 5-point Likert scale from strongly disagree to strongly agree.

\subsection{Validity and Reliability Instruments}

In early stages of testing statistical validity and reliability testing. Validity test is done is construct validity test, using factor analysis. Technique analysis factor is expected to find dimensions, indicators and grains of solid form constructs of variables tested. Items selection criteria based factor analysis, are commonly used limits degree of confidence sample or value of Kaiser Meyer-Olkin Measure of Sampling Adequacy (KMO)>0.50 when KMO value above 0.50 and loading factor $>0.40$ then item received is considered to be valid for further analysis. Table 1 Kaiser-Meyer-Olkin (KMO) value as commonality factors, and endorsement cumulative variation supports construct validity.

Table 1. Construct validity factor analysis

\begin{tabular}{|l|l|l|l|l|}
\hline Variables/Constructs & KMO value & Commonality value & Total factor & Cumulative variance (\%) \\
\hline Product quality & 0.82 & Values above 25 item 0.4 & 5 & 64.39 \\
\hline Price reasonableness & 0.88 & Values above 5 item 0.4 & 1 & 71.59 \\
\hline Brand image & 0.81 & Values above 5 item 0.4 & 1 & 66.85 \\
\hline Attitude & 0.80 & Values above 5 item 0.4 & 1 & 69.24 \\
\hline Intention & 0.79 & Values above 5 item 0.4 & 1 & 69.49 \\
\hline
\end{tabular}

The validity of test results showed that whole point statement amounted to 45 items declared valid because all variable has a value of $\mathrm{KMO}>0.50$ and loading factor $>0.4$. The reliability test was conducted to measure internal consistency instrument. Measurement reliability test used are coefficient Cronbach's alpha, with a limit of reliability if value Cronbach's alpha 
obtained exceeds 0.7 (Maholtra, 2004) or value Cronbach's alpha exceeding 0.8 is considered as reliability value is good (Hair et al., 2006).

Table 2. Value reliability

\begin{tabular}{|l|c|c|c|}
\hline Variables/Constructs & Amount items & number of items aborted & Cronbah's alpha $(\alpha)$ \\
\hline Product quality & 25 item & - & 0.92 \\
\hline Price reasonableness & 5 item & - & 0.90 \\
\hline Brand image & 5 item & - & 0.87 \\
\hline Attitude & 5 item & - & 0.89 \\
\hline Intention & 5 item & - & 0.89 \\
\hline
\end{tabular}

Reliability values for all constructs of 5 variables, namely: products quality, price reasonableness, brand image, attitude and intention exceeds 0.70 . Reliability test showed products quality is 0.92 ; price reasonableness is 0.90 ; a brand image is 0.87 ; attitude is 0.89 and intention are 0.89 . This shows that all questions in research instrument can be used to collect the data since a value of instrument reliability is good.

\section{Results and Discussion}

Characteristics of respondents indicated that ratio between men and women that is $68 \%$ male and $32 \%$ female. $32 \%$ based on marital status is not married and $68 \%$ were married. Judging from education mostly high-educated respondents $(68 \%)$, being educated junior and senior relatively small proportion, respectively $1 \%$ and $31 \%$. These results indicate that college graduates tend to have better knowledge about delivery service and a majority in urban. $27 \%$ is based on the work of civil servants, $41 \%$ of private employees, $9 \%$ of entrepreneurs, $2 \%$ military / police and 3\% other.

\subsection{Variable Measurement}

Measurement product quality by using five dimensions, namely: (1) Global Reach, (2) Reliability, (3) Transparency, (4) Speed and (5) Security. The results showed that speed with $\alpha=0.89$ and reliability with $\alpha=0.81$ is a primary measure of product quality express delivery services. Price reasonableness by using five indicators, namely: (1) reasonable rates; (2) reasonable rates; (3) affordable rates; (4) reasonable rates, and (5) the usual fare. The results show that the indicators of fair rates with $\alpha=0.89$; affordable rates $(\alpha=0.88)$ reasonable rates $(\alpha=0.85)$ and a rational tariff $(\alpha=0.82)$ is price reasonableness main measure.

Brand image by using five indicators, namely: (1) a popular brand image; (2) superior brand image; (3) good brand image; (4) brand image has a good reputation; (5) brand image has a good impression. The study results showed that brand image has a good reputation $(\alpha=0.87)$, good brand image ( $\alpha=0.86)$, popular brands image $(\alpha=0.80)$ and brand image have a good impression $(\alpha=0.80)$ is as key measures to brand image. Measurement of intervening variables attitudes using five indicators, namely: (1) happy to express delivery services; (2) 
likes to express delivery services; (3) excited to express delivery services; (4) happy for the existence of express delivery services; (5) think positively of express delivery services. The results show that the indicators of positive thinking to the express delivery services cognitive element $(\alpha=0.83)$; happy to express delivery services $(\alpha=0.81)$; like to express delivery services $(\alpha=0.89)$ both elements of affective and happy on the existence of express delivery services connative element $(\alpha=0.84)$ four indicators as attitude primary measure.

Furthermore, dependent variable intention to use express delivery services using five indicators, namely: (1) It will use express delivery services; (2) Want to use express delivery services; (3) Tendency to use express delivery services; (4) Willingness to use express delivery services; (5) Regarding use of these services in the future. The results showed that indicator will use express delivery services (attitude directed behavior) with $\alpha=0.84$ ); want to use express delivery services (trust and motivation) with $\alpha=0.88$ ) and a willingness to use express delivery services or intentions $(\alpha=0.87)$ as the three main measure on intention to use express delivery services.

\subsection{Structural Equation Model}

To test the hypothesis using SEM. Its test confirmed independent variable on dependent variable simultaneously. Hypothesis testing using SEM analysis to determine models suitability and items used in study through an absolute test of goodness-of-fit. According to Hair et al., (2006) there are six tests that need to be done and a model that should be considered to reach a stage of absolute goodness-of-fit when four of six tests that indicate that model had reached a stage of absolute goodness-of-fit. SEM analysis show that absolute goodness-of-fit test six of the good and meets suitability model, namely: value of likelihood ratio chi-square statistics $6.79(\mathrm{df}=3, \mathrm{p}=0.08)$; $\mathrm{GFI}=0.97$; $\mathrm{RMSEA}=0.08$; $\mathrm{AGFI}=0.89$; $\mathrm{CFI}=0.98$ and the NFI $=0.97$. Thus, this model is declared eligible to be used as a tool to confirm the theory that has been formed based on observational data.

Table 3. Determination of Goodness-of-Fit SEM

\begin{tabular}{|l|l|l|l|l|l|l|l|}
\hline Model & Dk & $X^{2}(\mathrm{p})$ & GFI & RMSEA & AGFI & CFI & NFI \\
\hline $\begin{array}{l}\text { product quality, price } \\
\text { reasonableness, brand image, } \\
\text { attitude andintention }\end{array}$ & 3 & $\begin{array}{l}6.79 \\
(0.79)\end{array}$ & 0.97 & 0.83 & 0.89 & 0.84 & 0.97 \\
\hline
\end{tabular}

Note. GFI = Goodness-of-fit index, RMSEA = Root mean square error of approximation, AGFI $=$ Adjusted goodness of fit index, $\mathrm{CFI}=$ comparative fit index, NFI $=$ normed fit index. $* * * \mathrm{p}<0.01$.

To determine influence product quality, price reasonableness, brand image, attitude and intention to use express delivery services can be seen from path coefficient between variables used. Attitudes are influenced by brand image, this is indicated by p-value is $0.00<0.01$. Product quality ( $p$ value is $0.39>0.05$ ) and price reasonableness ( $p$ value is $0.07>0.01$ ) did not affect attitude. While intention is influenced by attitude significantly ( $\mathrm{p}$-value 0.00 
$<0.01)$.

Table 4. Coefficient variable path

\begin{tabular}{|l|l|l|l|l|l|l|}
\hline \multicolumn{2}{|l|}{ Variables } & Estimate & S.E. & C.R. & P \\
\hline attitude & $<---$ & product quality & 0.03 & 0.03 & 0.86 & 0.39 \\
\hline attitude & $<---$ & brand image & 0.64 & 0.11 & 6.06 & $* * *$ \\
\hline attitude & $<---$ & price reasonableness & 0.15 & 0.08 & 1.80 & 0.07 \\
\hline intention & $<---$ & attitude & 0.76 & 0.06 & 12.61 & $* * *$ \\
\hline
\end{tabular}

Note. $\mathrm{CR}=$ Critical Ratio. $* * * \mathrm{p}<0,01$.

Figure 2 shows coefficient value between product quality and attitude is 0.02 ; price reasonableness and attitude is 0.15 ; brand image and attitude is 0.64 ; while attitude on intention is 0.76 .

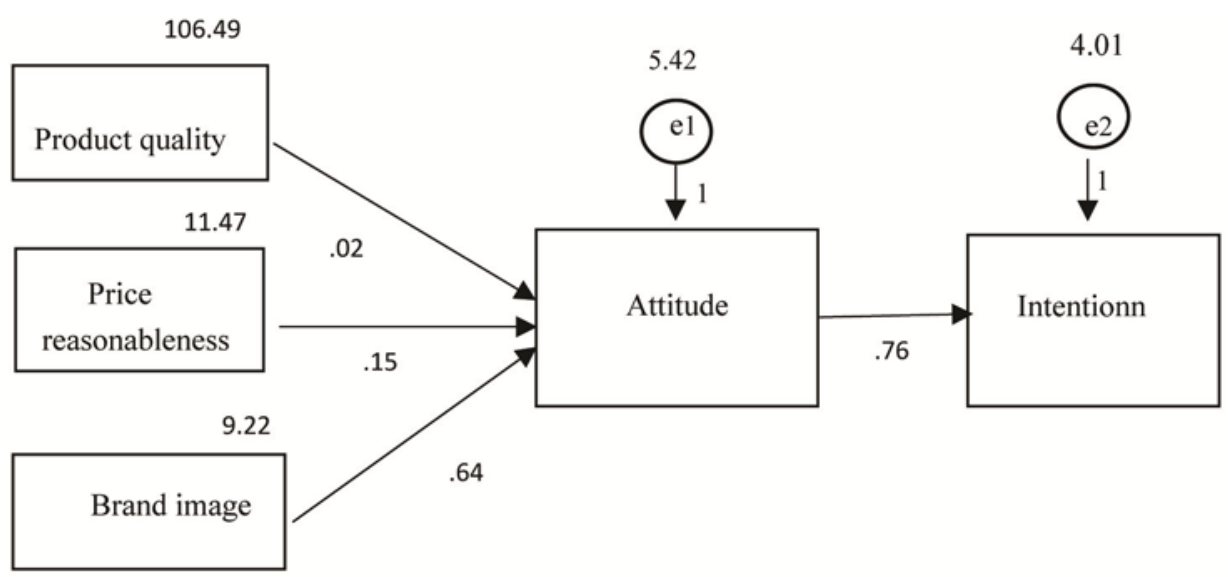

Figure 2. Model of product quality, price reasonableness, brand image, attitude and intention

\subsection{Hypothesis Testing Results}

In this study, hypotheses are tested by comparing p-value $<0.05$ or $\mathrm{p}<0.01$ to determine significance level. When a value of $\mathrm{p}<0.05$ or 0.01 then Ho is not supported, otherwise if p-value $>0.05$ or 0.01 Ho supported. Based on Table 4 research hypothesis testing can be described as follows:

Influence product quality against attitude is not significant, this is indicated by p-value is $0.39>0.01$ and has a regression coefficient of 0.03 which indicates that increase in product quality does not affect attitude. Critical ratio $(p=0.39>0.01)$ and C.R. of 0.86 indicates that influence of product quality on attitudes isn't meaningful. Thus, the hypothesis of positive influence on the product quality positive attitude established express delivery services are not 
supported.

Furthermore, showed price reasonableness effect on attitude is not significant. This is indicated by regression coefficient of 0.15 with a $C R$ at 1.80 and $p=0.07>0.01$, meaning price reasonableness does not affect attitude. Thus, the hypothesis price reasonableness positively influences attitudes express delivery service is not supported. The third hypothesis testing, brand image positively influence attitude on express delivery services is indicated by a positive regression coefficient for 0.64 with $\mathrm{CR}$ at 6.06 and $\mathrm{p}=0.00<0.01$. Results of this study significantly higher brand image higher influence express a delivery services attitude. Thus, the hypothesis that formed supported.

The results show that there is a positive influence attitude on intention to use express delivery services. This is indicated by regression coefficient of 0.76 with CR amounted to 12.61 and p-value $=0.00<0.01$. This means customers' positive attitudes influence intention to use express delivery services so that the fourth hypothesis that explains the attitude of mediating influence price reasonableness, product quality and brand image of customer's intention to use express delivery services established supported.

Furthermore, it is known that indirect influence product quality and price reasonableness on intention to use express delivery services is very low, respectively $\alpha=0.02$ and $\alpha=0.12$. While brand image indirect effect (with attitude) on intention to use express delivery services are adequate, namely $\alpha=0.49$.

\section{Discussion}

Product quality does not influence customer's attitude in using express delivery services at JNE. Product quality measures for express delivery services using standard Global Express Association (Frontier Economics 2015), which requires express delivery attributes Global Reach; Reliability; Transparency; Speed; Security. Found that speed with $\alpha=0.89$ and reliability with $\alpha=0.81$ are product quality main measure. This proves that the JNE is known as a reliable express delivery services company in speed and timely shipment of goods is supported. Results of these studies are not consistent with a study of Cronin \& Taylor (1992); Goode \& Harris (2004), which shows that products quality perception is a significant customer behavior predictors that affect behavioral intentions. This finding is not in line with the research (Cronin \& Taylor, 1992; Ahmad \& Kamal, 2002) indicated that service quality is antecendent intention to behave. Services quality more influence on intentions rather than customer attitudes. These results differ from findings of Goode \& Harris (2004) that product and services have proven positive effect on attitudes and intentions of customer behavior. Research findings are consistent that size of perceived quality of express delivery services based on timeliness (Kannan \& Tan, 2002; Cakravastia \& Takahashi, 2004) based costs (freight rates and prices) and risk (reliability, losses, and collateral).

Price reasonableness influence attitude is not significant and does not support hypothesis formed. The indicators used to measure price reasonableness are: (1) reasonable rates, (2) rational rates, (3) affordable rates, (4) a normal rate and (5) fair rates. The study found indicators of fair rates with $\alpha=0.89$, affordable rates $(\alpha=0.88)$, reasonable rates $(\alpha=0.85)$ 
and a rational tariff $(\alpha=0.82)$ is main measure of price reasonableness. This condition reflects that high price sensitivity does not affect customer perception of express delivery services JNE. This is consistent with the findings Karampour \& Ahmadinejad (2014) price sensitivity does not affect customer's purchase intention. Results of price reasonableness are not consistent with Colgate \& Hedge (2001) findings that behavioral prices affect a decision to switch customers to products / services and Keaveney (1995) studies about inconclusive price with behavioral intention indicated their intention to behave customers significantly affected services price is low. These results are not consistent also with a study of Zeithaml et al. (1988) if price reasonableness of service innovation is accepted, then customer to be positive about product / service and receive a higher price. The results study is consistent with research Mittal et al. (1998) found no significant relationship that customer's intention to behave is influenced by service price is high.

Brand image influence on attitudes, that means its higher brand image influence on express delivery services attitude. Brand image indicators shows that a good reputation $(\alpha=0.87)$, brand image of good $(\alpha=0.86)$, popular brands image $(\alpha=0.80)$ and brand image have a good impression $(\alpha=0.80)$ is main measure. This is consistent with (Aaker, 1991; Aaker, 2004) opinion that quality perception can show a superior differentiation of products or services and make consumers think selectively to brand and services described by brand products or services that customers will use. These results are consistent findings (Hsieh et al., 2004; Karampour \& Ahmadinejad, 2014) that brand image elaborating memories, beliefs and preferences of customer's attitude toward a brand, then brand image and perception of corporate image influence on intention and brand purchase behavior. Also consistent with studies Matthiesen \& Phau (2010) that brand image is formed by quality perception as their experience result. The company's brand influence positive customers attitudes and behavior in line with Blomback \& Axelsson (2007) findings that brand is formed by interaction with features unity that is intangible and tangible representing the brand as well as consistent with studies Ogba \& Tan (2009) indicate that brand image influence attitude. Good customer perception could arise if a brand has a unique advantage / superior, good reputation, popular, nice and provide the best service (Aaker, 1997; Kotler \& Keller, 2012).

The results show customers' positive attitudes influence intention to use express delivery services, so hypothesis that formed supported. Thus, intention to use express delivery services is mediated by attitudes toward product quality, price reasonableness, and brand image. The indicators used to measure attitude are: positive thinking as a cognitive element $(\alpha=0.83)$; happiness $(\alpha=0.81)$; like to express delivery services $(\alpha=0.89)$ both elements of affective and happy on existence of express delivery services connative element $(\alpha=0.84)$, these four indicators as a attitude primary measure. While intention indicators reveal attitude directed behavior with $\alpha=0.84$ ); want to use express delivery services (trust and motivation) with $\alpha=0.88)$ and a willingness to use express delivery services or intentions $(\alpha=0.87)$ as three main intention measure. This consistency can be seen from Multi Dimension Model (Rosenberg \& Hovland, 1995) that attitude as a construct by cognitive, affective and conative. Attitude used to describe individual's desire to determine a positive attitude on express delivery services. This finding is consistent with Ehigie (2006) study that positive consumers 
attitude is a critical factor associated with customer expectations, perceived service quality, commitment to product, brand or service companies that generate purchase intent. Similar is described by Donio et al. (2006); Brunner et al. (2008) positive customers attitude are not sensitive to negative information and positive customers attitude fully take effect to brand. These results are consistent with research (Ehigie, 2006; Donio et al., 2006; Brunner et al., 2008) obtained the fact that customers' positive attitude towards use of services will increase intention to use services.

\section{Conclusion}

Influence between variables in structural equation modeling, in general, does not support the results of previous studies, such as product quality and price reasonableness is not consistent with the study (Cronin \& Taylor, 1992) that product quality perceived and services are predictors of positive attitudes and behavior intention antecendent subscribers. The findings further showed no consistent also with findings (Keaveney, 1995; Colgate \& Hedge, 2001) that price reasonableness influence positive attitude customers. However, results of studies on price reasonableness in line with (Mittal et al., 1998; Karampour \& Ahmadinejad, 2014) studies indicating price does not affect customer's purchase intention.

The findings indicate that brand image positively influences attitudes. These results support previous studies (Aaker, 2004) that quality perception shows superior differentiation of products or services and customers to the brand and think selectively used services. These results are consistent findings (Hsieh et al., 2004; Karampour \& Ahmadinejad, 2014) that brand image elaborating memories, beliefs and preferences of customer's attitude toward a brand, then brand image and perception of corporate image influence on intention and purchase behavior brand, in line with studies (Blomback \& Axelsson, 2007; Ogba \& Tan, 2009; Matthiesen \& Phau, 2010) brand image influence positive customers attitude. Good customer perception will appear when the brand has a unique advantage / superior, good reputation, popular, nice and provide the best service (Aaker, 1997; Kotler \& Keller, 2012). This shows brand image directly describes product quality.

The study showed mediating role attitudes towards an intention to use express delivery services to sharpen study (Rosenberg \& Hovland, 1995) that a construct of cognitive, affective and conative able to explain desire individuals to determine a positive attitude. Construction positive attitude (Ehigie, 2006) is a critical factor closely related to customer expectations, perceived services quality. Similar findings (Donio et al., 2006; Brunner et al., 2008) which affect-laden of a brand that a positive attitude will enhance customer intention to use express delivery services.

The study findings role of mediating a positive attitude and intention to use express delivery service at JNE, but there is limited research in the application of its main model's adoption of quality standards of products / services adopted by the Global Express Association, which requires attributes Global Reach; Reliability; Transparency; Speed; Security. This standard has actually been widely used by similar companies become global players, such as FedEx, TNT, UPS or DHL International. Trends in global express delivery services which should be followed by application of the same standards to facilitate interconnection and 
interoperability. With common standards adoption is expected to provide a complete picture about express delivery services nationally and globally.

\section{Implication}

Implications research can be noted that company's express delivery services to adopt global standards to improve interconnection and interoperability in a delivery of goods. For marketers the future need to explore advantages of product quality standards / express delivery services and enhance brand image by building an image that company is a global company. This is consistent with level customers awareness needs and expresses delivery services use in line with rising electronic purchasing trends in national and global.

\section{References}

Aaker, D. (2004). Brand Portofolio Strategy. Creating: Relevance, Differentiation, Energy, and Leverage. New York: The Free Press.

Aaker, J. L. (1997). Dimensions of Brand Personality. Journal of Marketing Research, 34(3), 347-356. http://dx.doi.org/10.2307/3151897.

Ahire, S. L., Matthew, A. W., \& Golhar, D. Y. (1996). Quality management in TQM versus non-TQM firms: an empirical investigation. International Journal of Quality \& Reliability Management, 13(8), 8-27. http://dx.doi.org/10.1108/02656719610128466

Ahmad, J., \& Kamal, N. (2002). Customer satisfaction and retail banking: an assessment of some of the key antecedents of customer satisfaction in retail banking. International Journal of Bank Marketing, 20(4/5), 146-161.

Ajzen, I. (1991). The theory of planned behavior. Organizational Behavior and Human Decision Processes, 50(2), 179-211. http://dx.doi.org/10.1016/0749-5978(91)90020-T

Ajzen, I. (2001). Nature and operation of attitudes. Annual Review of Psychology, 52, 27-58. http://dx.doi.org/10.1146/annurev.psych.52.1.27

Alwi, S. F. S., \& Rui, V. D. S. (2008). The link between offline brand attributes and corporate brand image in book stores. Journal of Product and Brand Management, 17(3), 175-187. http://dx.doi.org/10.1108/10610420810875098

Anisimova, T. A. (2007). The effect of corporate brand attributes on attitudinal and behavioural consumer loyalty. Journal of Consumer Marketing, 24(7), 395-405. http://dx.doi.org/10.1108/07363760710834816

Anoraga, P. (2000). Manajemen Bisnis. PT. Rineka Cipta, Jakarta.

Arnould, E., Price, L., \& Zinkan, G. (2005). Consumers. Singapore: McGraw-Hill/Irwin.

Aydin, S., \& Özer, G. (2005). The analysis of antecedents of customer loyalty in the Turkish mobile telecommunication Market. European Journal of Marketing, pp. 910-925. http://dx.doi.org/10.1108/03090560510601833

Bagozzi, R. P., \& Yi, Y. (1991). Multitrait-multimethod matrices in consumer research. 
Journal of Consumer Research, 17, 426-439. http://dx.doi.org/10.1086/208568

Bienstock, C. C., \& Royne, M. B. (2010). Technology acceptance and satisfaction with logistics services. The International Journal of Logistics Management, 21(2), 271-292. http://dx.doi.org/10.1108/09574091011071951

Blomback, A., \& Axelsson, B. (2007). The role of corporate brand image in the selection of new subcontractors. Journal of Business and Industrial Marketing, 22(6), 418-430. http://dx.doi.org/10.1108/08858620710780181

Brunner, T. A., Markus, S., \& Opwis, K. (2008). Satisfaction, image and loyalty: new versus experienced customers. European Journal of Marketing, 42(9/10), 1095-1105. http://dx.doi.org/10.1108/03090560810891163

Cakravastia, A., \& Takahashi, K. (2004). Integrated model for supplier selection and negotiation in a make-to-order environment. International Journal of Production Research, 42(21), 4457-4474. http://dx.doi.org/10.1080/00207540410001727622

Chaoprasert, C., \& Elsey, B. (2004). Service quality improvement in Thai retail banking and its management implications. ABAC Journal, 24(1), 47-66.

Chin, S. H., Soh, K. L., \& Wong, W. P. (2013). Impact of Switching Costs on the Tripartite Model—Third Party Logistics. Journal Management, 3(2), 79-88.

Chitty, B., Ward, S., \& Chua, C. (2007). An application of the ECSI model as a predictor of satisfaction and loyalty for backpacker hostels. Marketing Intelligence and Planning, 563-580. http://dx.doi.org/10.1108/02634500710819941

Choi, J., \& Fishbach, A. (2011). Choice as an End Versus a Means. Journal of Marketing Research, 48(3), 544-554. http://dx.doi.org/10.1509/jmkr.48.3.544

Colgate, M., \& Hedge, R. (2001). An investigation into the switching process in retail banking services. International Journal of Bank Marketing, 19(5), 201-212. http://dx.doi.org/10.1108/02652320110400888

Colonna, F. (1997). La qualita Ánellalogistica. Logistica Management, 77, 49-52.

Cronin, J. J., \& Taylor, S. A. (1992). Measuring service quality: a reexamination and extension. Journal of Marketing, 56, 55-68. http://dx.doi.org/10.2307/1252296

Daniel, S. D. (2003). Express Delivery and the Postal Sector in the Context of Public Sector Anti-Competitive Practices. Northwestern Journal of International Law \& Business, 23(2).

Donio', J., Massari, P., \& Passiante, G. (2006). Customer satisfaction and loyalty in a digital environment: an empirical test. Journal of Consumer Marketing, 23(7), 445-457. http://dx.doi.org/10.1108/07363760610712993

Ehigie, O. B. (2006). Correlates of customer loyalty to their bank a case study in Nigeria. International Journal of Bank Marketing, 24(7), 494-508. http://dx.doi.org/10.1108/02652320610712102 
Fawcett, S. E., Calantone, R., \& Smith, S. R. (1996). An Investigation of the Impact of Flexibility on Global Reach and Firm Performance. Journal of Business Logistics, 17(2), 168-196.

Fawcett, S. E., Calantone, R., \& Smith, S. R. (1997). Delivery Capability and Firm Performance in International Operations. International Journal Production Economics, 51, 191-204. http://dx.doi.org/10.1016/S0925-5273(97)00051-0

Fishbein, M., \& Ajzen, I. (2010). Predicting and changing behavior: The reasoned action approach. New York: Psychology Press Taylor.

Frontier Economics. (2015). Express Delivery and Trade Facilitation: Impacts on the Global Economy. A Report Prepared for The Global Express Association. Frontier Economics Ltd, London.

Gerrad, P., \& Cunningham, J. B. (2004). Consumer Switching Behaviour in the Asian Banking Market. Journal of Services Marketing, 18(3), 215-223. http://dx.doi.org/10.1108/08876040410536512

Goode, M. M. H., \& Harris, L. C. (2006). Online behavioural intentions: an empirical investigation of antecedents and moderators. European Journal of Marketing, 41(5), 512-536.

Gronroos, C. (1984). A Service Quality Model and its Marketing Implications. European Journal of Marketing, 18(4). http://dx.doi.org/10.1108/EUM0000000004784

Gronroos, C. (1990). Relationship approach to marketing in service contexts: the marketing and organizational behaviour interface. Journal of Business Research, 20(January), 3-11. http://dx.doi.org/10.1016/0148-2963(90)90037-E

Hair, J. F., Black, W. C., Babin, B. J., Anderson, R. E., \& Tatham, R. L. (2006). Multivariate Data Analysis (6th ed.). NJ: Pearson Prentice-Hall.

Hawkins, D. I., Best, R. J., \& Coney, K. A. (2004). Consumer Behavior-Building Marketing Strategy. New York: McGraw-Hill.

Hong, I., \& Cha, H. (2013). The mediating role of consumer trust in an online merchant in predicting purchase intention. International Journal of Information Management, 33, 927-939. http://dx.doi.org/10.1016/j.ijinfomgt.2013.08.007

Hooper, D., Coughlan, J., \& Mullen, M. (2008). Structural Equation Modelling: Guidelines for Determining Model Fit. Electronic Journal of Business Research Methods, 6(1), 53-60.

Hsieh, M. H., Pan, S. L., \& Setiono, R. (2004). Product-, corporate-, and country-image dimensions and purchase behavior: A multicountry analysis. Journal of the Academy of Marketing Science, 32(3), 251-270. http://dx.doi.org/10.1177/0092070304264262

Imran, A., Safwan, N., \& Rehman, K. (2010). Determinants of consumer retention in cellular industry. Journal of Business Research, 71, 515-522.

Jin, C. H. (2011). The role of animation in the consumer attitude formation: Exploring its 
implications in the tripartite attitudinal model. Journal of Targeting, Measurement and Analysis for Marketing, 19, 99-111. http://dx.doi.org/10.1057/jt.2011.8

Kannan, V. R., \& Tan, K. C. (2002). Supplier selection and assessment: Their impact on business performance. Journal of Supply Chain Management, 38(4), 11. http://dx.doi.org/10.1111/j.1745-493X.2002.tb00139.x

Karampour, A., \& Bahareh, A. (2014). Kuwait Chapter of Arabian. Journal of Business and Management Review, 3(7).

Keaveney, S. M. (1995). Customer switching behavior in service industries: an exploratory study. Journal of Marketing, 59(2), 71-82. http://dx.doi.org/10.2307/1252074

Keller, K., \& Lehmann, D. (2003). How Do Brands Create Value? Marketing Management, 12(3), 26.

Kotler, P., \& Armstrong, G. (2010). Principles of Marketing (13th ed.). New Jersey: Pearson Prentice Hall.

Kotler, P., \& Keller, K. L. (2012). Marketing Management (14th ed.). New Jersey: Pearson-Prentice Hall.

Lee, B. C. Y. (2012). The determinants of consumer attitude toward service innovation-the evidence of ETC system in Taiwan. Journal of Services Marketing, 26(1), 9-19. http://dx.doi.org/10.1108/08876041211199689

Lee, K. S., \& Tan, S. J. (2003). E-Retailing versus physical retailing: a theoretical model and empirical test of consumer choice. Journal of Business Research, 56(11), 877-885. http://dx.doi.org/10.1016/S0148-2963(01)00274-0

Lefkoff-Hagius, R., \& Mason, C. H. (1993). Characteristic, Beneficial, and Image Attributes in Consumer Judgments of Similarity and Preference. Journal of Consumer Research, 20(1), 100-110. http://dx.doi.org/10.1086/209336

Leong, Y. P., \& Wang, Q. (2006). Impact of Relationship Marketing Tactics (RMTs) on Switchers and Stayers in a Competitive Service Industry. Journal of Marketing Management, pp. 25-59.

Li, X., \& Petrick, J. F. (2008). Reexamining the Dimensionality of Brand Loyalty: A Case of the Cruise Industry. Journal of Travel and Tourism Marketing, 25(1), 68-85. http://dx.doi.org/10.1080/10548400802164913

Liu, J. C., Liu, W., \& Liu, Y. H. (2014). Express company's vehicle routing optimization by multiple-dynamic saving algorithm. Journal of Industrial Engineering and Management, 7(2), 390-400. http://dx.doi.org/10.3926/jiem.966

Malhotra, N. K. (Ed.) (2007). Review of Marketing Research, 3. Armonk, NY, USA: M.E. Sharpe, Inc. http://dx.doi.org/10.1108/S1548-6435(2007)3

Martenson, R. (2007). Corporate brand image, satisfaction and store loyalty. International 
Journal of Retail and Distribution Management, 35(7), 544-555. http://dx.doi.org/10.1108/09590550710755921

Matthiesen, I. M., \& Phau, I. (2010). Brand image inconsistencies of luxury fashion brands A buyer-seller exchange situation model of Hugo Boss Australia. Journal of Fashion Marketing and Management, 202-218. http://dx.doi.org/10.1108/13612021011046066

Mentzer, J. T., \& Flint, D. J. (1999). Developing a logistics service quality scale. Journal of Business Logistics, 20(1), 9-32.

Mentzer, J. T., \& Flint, D. J. (2001). Logistics service quality as a segment-customized $\begin{array}{llll}\text { process. Journal of } & \text { 82-104. }\end{array}$ http://dx.doi.org/10.1509/jmkg.65.4.82.18390

Mittal, B., \& Lassar, W. M. (1998). Why do customers switch? The dynamics of satisfaction versus loyalty. The Journal of Services Marketing, 12(3), 177. Bingley, West Yorkshire: Emerald Group Publishing, Limited. http://dx.doi.org/10.1108/08876049810219502

Mowen, J. C., \& Minor, M. (2001). Consumer Behavior: A Framework. New Jersey: Prentice Hall.

Narayanan, S., Marucheck, A. S., \& Handfield, R. B. (2009). Electronic data interchange: research review and future directions. Decision Sciences, 40(1), 121-163. http://dx.doi.org/10.1111/j.1540-5915.2008.00218.x

Nguyen, N., \& Le Balnc, G. (1998). The mediating role of corporate image on customers' retention decisions: an investigation in financial services. International Journal of Bank Marketing, 16(2), 52-65. http://dx.doi.org/10.1108/02652329810206707

Ogba, E. I., \& Tan, Z. (2009). Exploring the impact of brand image on customer loyalty and commitment in China. Journal of Technology Management in China, pp. 132-144. http://dx.doi.org/10.1108/17468770910964993

Oliver, L. R. (1999). When consumer loyalty? Journal of Marketing, pp. 33-44. http://dx.doi.org/10.2307/1252099

Oxford Economic Forecasting. (2009). The impact of the express industry on the global economy. Unpublished report. [Online] Available: http://www.oef.com

Parasuraman, A., Zeithaml, V. A., \& Berry, L. L. (1988). SERVQUAL: a multiple-item scale for measuring consumer perceptions of service quality. Journal of Retailing, 64(Spring), $12-40$.

Parasuraman, A., Zeithaml, V. A., \& Malhotra, A. (2005). ES-QUAL: Amultiple-item scale for assessing electronic service quality. Journal Service Research, 7(3), 213-233. http://dx.doi.org/10.1177/1094670504271156

Pei, Z., Paswan, A., \& Yan, R. (2014). E-tailer's return policy, consumer's perception of return policy fairness and purchase intention. Journal of Retailing \& Consumer Services, 21(3), 249-257. http://dx.doi.org/10.1016/j.jretconser.2014.01.004 
Pina, J., M., Martinez, E., Chernatony, D. L., \& Durry, S. (2006). The effect of service brand extensions on corporate image an empirical model. European Journal of Management, pp. 174-197.

Rafiq, M., \& Jaafar, H. S. (2007). Measuring Customers' Perception of Logistics Service Quality of 3PL Service Providers. Journal of Business Logistics, 28(2). http://dx.doi.org/10.1002/j.2158-1592.2007.tb00062.x

Rahman, S. (2006). Quality management in logistics: an examination of industry practices. Supply Chain Management: An International Journal, 11(3), 233-240. http://dx.doi.org/10.1108/13598540610662130

Richey, R. G., Daugherty, P. J., \& Roath, A. (2007). Firm technological readiness and complementarity: capabilities impacting logistics service competency and performance. $\begin{array}{llll}\text { Journal of } & \text { Business } & \text { Logistics, } & \text { 28(1), }\end{array}$ http://dx.doi.org/10.1002/j.2158-1592.2007.tb00237.x

Rosenberg, M. J., \& Hovland, C. I. (1995). Cognitive, affective, and behavioral components of attitudes. In C. I. Hovland \& M. J. Rosenberg (Eds.), Attitude organization and change: An analysis of consistency among attitude components (pp. 1-14). New Haven, CT: Yale University Press.

Russell, D. M., \& Hoag, A. M. (2004). People and information technology in the supply chain: Social and organizational influences on adoption. International Journal of Physical $\begin{array}{llll}\text { Distribution \& } \quad \text { Logistics } \quad \text { Management, } & \text { 34(1/2), }\end{array}$ http://dx.doi.org/10.1108/09600030410526914

Schiffman \& Kanuk. (2000). Consumers Behavior. New Jersey: Prentice-Hall, Inc.

Sharma, N., \& Patterson, P. G. (2000). Switching cost, alternative attractiveness and experiences as moderators of relationship commitment in professional consumer services. International Journal of Service Industry Management, 11(5), 470-490. http://dx.doi.org/10.1108/09564230010360182

Stank, T. P., Goldsby, T. J., Vickery, S. K., \& Savitskie, K. (2003). Logistics service performance: estimating its influence on market share. Journal of Business Logistics, 24(1), 27-55. http://dx.doi.org/10.1002/j.2158-1592.2003.tb00031.x

Tarkiainen, A., \& Sundqvist, S. (2005). Subjective norms, attitudes and intentions of Finnish consumers in buying organic food. British Food Journal, 107(11), 808-822. http://dx.doi.org/10.1108/00070700510629760

Vahid, R., \& Aidin, T. N., (2012). The Role of Attitudes and Decision Making on Product Choice Case Study: Cellulars Phones. International Business Research, 5(5).

Valentini, S., Montaguti, E., \& Neslin, S. A. (2011). Decision Process Evolution in Customer Channel Choice. Journal of Marketing, 75(6), 72-86. http://dx.doi.org/10.1509/jm.09.0362

Wang, Y. S., Lin, H. H., \& Liao, Y. W. 2010. Investigating the individual difference 


\section{Macrothink}

Case Studies in Business and Management

ISSN 2333-3324

2016, Vol. 3, No. 2

antecedents of perceived enjoyment in the acceptance of blogging. World Academy of Science, Engineering and Technology, 67.

Wankhade, L., \& Dabade, B. M. (2006). TQM with Quality Perception: A system Dinamic $\begin{array}{lllll}\text { Approached. The TQM } & \text { 341-357. }\end{array}$ http://dx.doi.org/10.1108/09544780610671020

Webb, T. L., \& Sheeran, P. (2006). Does Changing Behavioral Intentions Engender Behavior Change? A Meta-Analysis of the Experimental Evidence. Psychological Bulletin, the American Psychological Association 2006, 132(2), 249-268. http://dx.doi.org/10.1037/0033-2909.132.2.249

Wen, Y. L. (2010). Customer Switch Behaviour-A Case of Travel Agencies. Departement of Managerial Economics, Nanhua University, 32, Chung Keng Li, Dalin, Chiagi, Taiwan.

Werner, P. (2004). Reasoned Action and Planned Behavior. In S. J. Peterson \& T. S. Bredow (Eds.), Middle range Theories: Application to Nursing Research. Philadelphia: Lippincott Williams \& Wilkins.

Zanna, M. P., \& Rempel, J. K. (1988). Attitudes: A new look at an old concept. In D. Bar-Tal \& A. W. Kruglanski (Eds.), The social psychology of knowledge (pp. 315-334). Cambridge, England: Cambridge University Press.

Zeithaml, V. A. (1988). Consumer Perception of Price, Quality and Value: A Means-End Model and Synthesis of Evidence. Journal of Marketing, 52(July), 2-22. http://dx.doi.org/10.2307/1251446

\section{Copyright Disclaimer}

Copyright for this article is retained by the author(s), with first publication rights granted to the journal.

This is an open-access article distributed under the terms and conditions of the Creative Commons Attribution license (http://creativecommons.org/licenses/by/3.0/). 